Jurnal Pena Sains Vol. 6, No. 1, April 2019

p-ISSN: 2407-2311

e-ISSN: 2527-7634

\title{
THE DEVELOPING OF MODUL ON SCIENCE SCHOOL MATERIAL WITH PANCASILACHARACTER
}

\author{
M. Aji Fatkhurrohman ${ }^{1}$ and Wahyu Jati Kusuma ${ }^{2}$ \\ ${ }^{1}$ Pendidikan IPA, Fakultas Keguruan dan Ilmu Pendidikan, Universitas Pancasakti Tegal \\ Tegal, 52122, Indonesia \\ ajifatkhur.pipa@gmail.com \\ ${ }^{2}$ Pendidikan Pancasila dan Kewarganegaraan, Fakultas Keguruan dan Ilmu Pendidikan, \\ Universitas Pancasakti Tegal \\ Tegal, 52122, Indonesia \\ wahyujatikusuma@gmail.com
}

Accepted: November 11, 2018

Published: April 30, 2019

DOI: http://doi.org/10.21107/jps.v6i1.4533

\begin{abstract}
The characteristics of the Pancasila values of the younger generation in the present era are depleting. This can be seen from the emergence of cases that occur now, from radical understanding to the Caliphate. The results of the Republic of Indonesia's National Police study stated that many students were involved in radical groups, generally science students. In this regard, efforts need to be made to improve the characteristics of Pancasila in science students. The purpose of this study is to develop, determine validity, and the level of readability of the School Science Material study module characterized by Pancasila. This research is a development research. The research subject was the science education student at Pancasakti University Tegal. The research steps include needs analysis, development stage, the process of making the School Science Material Study module characterized by Pancasila, validation by validator, evaluation, and refinement, product testing, final product module, School Science Material Study, characterized by validity and readability. Validation was done with an expert validator. Limited scale testing is used to test the level of readability. The results of the research in the form of the development of the School Science Material Study module characterized by Pancasila, the subject of Electricity and Magnetism, which has high validity and an easily understood level of readability.
\end{abstract}

Keywords: School Science Study, module, Pancasila

${ }^{1}$ Corresponding Author 


\section{The Developing of Modul on Science School Material with Pancasila Character}

\section{Introduction}

The Pancasakti Tegal University Science Education Study Program has a vision "The realization of a Study Program that produces graduates who have the competence to conduct Natural Sciences learning in Schools, excel in mastering scientific literacy and Pancasila spirit" (Science Education, 2015). Based on this vision, the students of Pancasakti Tegal University's Science Education Study Program directed at forming the character of Pancasila that integrated into the science it has.

The characteristics of Pancasila values in the younger generation in the present era are depleting (Republika, 2014). The events that occur in our country today, from the understanding of radicalism to the Caliphate are a reflection of the thin values of Pancasila nationalism in the younger generation. Many factors cause the depletion of Pancasila values in the younger generation, one of which is the lack of socialization about the Pancasila ideology (Badarudin in Republika, 2014). This was also evident from the Pancasila education courses in higher education, with an average of only two credits during higher education. In the UPS Tegal Science Education Study Program, during the study period, the Pancasila Education students only took two credits (Science Education, 2015).

The problems of the Indonesian people lately cannot be separated from the weak character of college graduates. Student character cannot appropriately be developed through the learning process that exists in universities in Indonesia. This opinion is by the advice of Manullang (2013) who said that character crises occur in the nomographic and ideographic perspectives. The nomothetic perspective must be healthy because it is very influential on attitude, thinking, commitment and competence. Ideographic perspectives refer to productive and creative abilities individually. If this character has not developed, then the reference to good or bad behavior becomes less clear. As a result, all groups or individuals make their own references so that they are prone to horizontal conflicts in the community.

The results of the study of the National Police of the Republic of Indonesia (Kompas, 2017) stated that many students were involved in radical groups and generally the students involved were those from scientific groups. The involvement of science students in militant groups is one indication of the weak characteristics of Pancasila in science students. In this regard the need for character education to instill the character of Pancasila in science students. This is as revealed by Judiani (2010) that character education is a necessity, because learning does not only make students smart, but also has a character so that it can benefit both themselves and others, and not vice versa, it causes damage. Khusniati (2012) also said that related to the national commitment about the need for character education, and it could be implemented by integrating character education in learning, one of which is science learning.

Students of the science education Study Program are one of the pre-service teachers of science in the coming era. Graduates of science education are authorized to become junior high school Science Teachers (Wilujeng, 2012). As the forerunner of educators in the coming era, science education students in addition to having responsibility for themselves, they are also responsible for their students in the future. One of the duties of students is to improve the characteristics of the Pancasila in their students by integrating their science. Not the other way, instilling 


\section{Fatkhurrohman and Kusuma}

radicalism in students. That is because teachers are the primary determinant of success in the learning process. Schacter (2006) also said that teacher performance is an input variable that is very important in improving student learning achievement.

The subject of the school science material is one of the compulsory course in the curriculum of the Science Education Program at Pancasakti Tegal University. This course weighs three credits. This course aims to provide knowledge about junior high school science and its application in technology. Also, this course is one of the provisions to enhance the ability to integrate science in the Pancasila in science education students.

Integration of values through learning materials by teachers is currently needed to produce graduates with character. That is by Amir (2013) who stated the Indonesia Teachers who have spirited Pancasila and loyal to the Constitution of 1945, take responsibility for the realization of the ideals of the proclamation of independence of the Republic of Indonesia August 17, 1945. That means that the Pancasila serves as a reflection of the educational character of the Indonesian nation in shaping the national identity of Indonesia as a great nation, modern, dignified and civilized. Nevertheless, the authors argue that the views of education thinkers Indonesia still partial.

The results of the lecturers' observation of the School Science Materials subject during the lecture process, the characteristics of Pancasila values that integrated into science have not been formed optimally. It can be seen from the lack of mutual respect, honesty, and tolerance towards others. One of the causal factors is not optimal Pancasila characteristics in students other than the Pancasila Education course which is only two credits, namely the absence of a specific module for School Science Material Studies that integrates the characteristics of Pancasila in science.

Existing constraints prove the need for progressive steps in improving the condition of education in Indonesia, especially regarding character education. According to Kristiawan (2015), the challenges ahead are the mental revolution, and character education is two aspects that are related and harmonious with each other. Both of these can provide a complete problem-solving in the formation of personal Indonesian human resources that are clever and noble. Mental revolution and character education start from the classroom since students get knowledge. If the mental revolution and character education successfully implemented, then the gate of "new Indonesia" was opened.

Seeing the fact that the characteristics of the students of the science education program are low and there are no modules for the School Science Material Study in which the Pancasila values integrated, it is necessary to develop a module for the Study of School Science Material Characteristic of Pancasila.

The problems in this study are: (1) How are the characteristics of the School Science Material Study Module characterized by Pancasila? (2) How is the validity of the module Science School Study Material characterized by the Pancasila developed? (3) What is the level of readability of the School Science Material Study module characterized by the Pancasila developed? 
The Developing of Modul on Science School Material with Pancasila Character

\section{Research Method}

This research is development research, with a focus on the subject of electricity and magnetism. In this study, the product to be developed is a module on School Science
Material Study characterized by Pancasila, the subject of electricity and magnetism.

The research and development design in this study is illustrated in Figure 1.

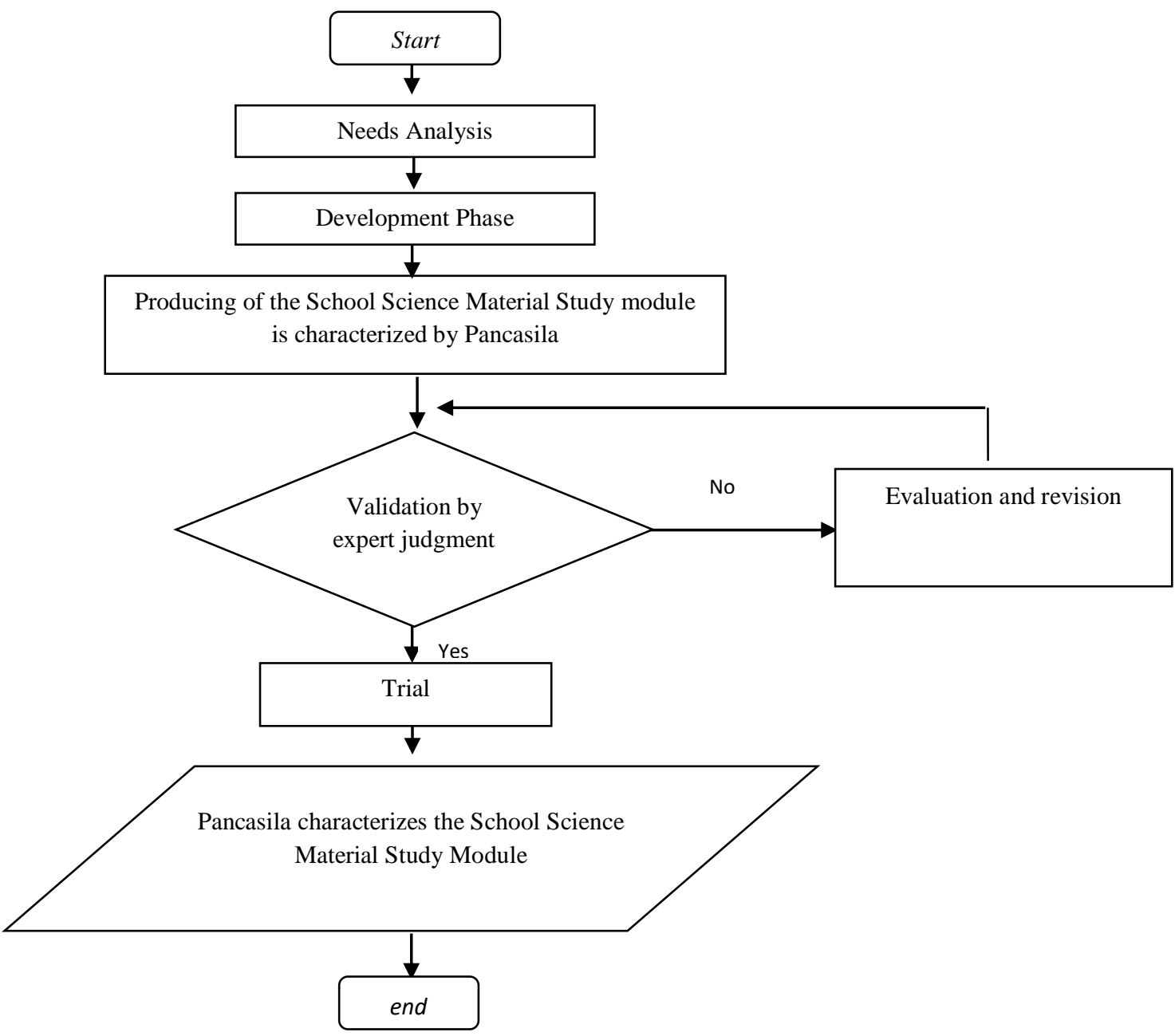

Figure 1. Flowchart Design Development Module Study of School Science Material Characteristics of Pancasila (Modification from Sadiman et al.1996)

The instrument used in this study was a non-test instrument. Non-test instruments include the module validation sheet, School Science Study Material, characterized by Pancasila and cloze procedure tests.

On the validation of the module sheet, there are eight aspects of testing validity assessment module. The assessment includes the following aspects, namely instructional objectives, characteristics of Pancasila in the module, conformance, rational, language, content modules, suppleness, and physical form. Each element is rated at a minimum of 1 and a maximum of 4 assessment categories listed in table 1 . 


\section{Fatkhurrohman and Kusuma}

Table 1. The Assessment Categories of Module

\begin{tabular}{llll}
\hline No & Categories & Recommendation & Score \\
\hline 1 & Very high validity & Can be used without revision & $\mathrm{V}>28$ \\
2 & High validity & Can be used with few revisions & $23<\mathrm{V} \leq 28$ \\
3 & Medium validity & Can be used with major revisions & $13<\mathrm{V} \leq 23$ \\
4 & Low validity & Cannot be used & $\mathrm{V} \leq 13$ \\
\hline
\end{tabular}

The Module on School Science Material Study characterized by Pancasila is said to be valid if at least in the category of high validity with the score obtained more than 23 .

The cloze procedure test measured the level of readability in this study. This test aims to find out whether students understand easy or difficult modules. Bermouth in Widodo (1993) stated that the limits of interpretation criteria for module readability tests were: upper limit of $57 \%$, lower limit of $37 \%$, and the midpoint of $47 \%$. The limit interprets that if students get a test score of less than $37 \%$, it is challenging to understand reading material. If the test score is $57 \%$ or more, students can learn independently from the module. This study takes the $10^{\text {th }}$ word in each sentence.

The technique used to determine the level of readability of instructional material texts, Sudijono (2008) states that the level of readability can calculate by equation.:

$$
P=\frac{f}{N} x 100 \%
$$

$\mathrm{P}=\quad$ Percentage of assessment

$\mathrm{f}=$ Scores obtained by students

$\mathrm{N}=$ Total score

\section{Results and Discussion}

The urgency of character education in tertiary learning is necessary to produce graduates who have not only skills and skills but also graduates who are also equipping with good character. Susanti (2013) said that character education in tertiary institutions is essential to form and build students to be characterless following the liberal values of the Indonesian State ideology and strengthen the character gained by students at the previous level of education. Also, character education is crucial to be applied in universities because many scholars are smart but have no character, so they cannot compete with scholars from other countries.

The development of the ideal value of the Pancasila character according to Rachmah (2013) can be applied by giving actions and inserting character values in learning. In this science material study module, the application of Pancasila character values is done by entering in science learning material, so that when students learn the material automatically, students also learn character values related to each subject matter.

The School Science Module Study Material characterized by Pancasila has the value of the five precepts, namely: the first principle which includes the value of being grateful and appreciating God's creation; second principle, which includes the value of honesty and tolerance; third principle which includes the value of usability in society/nation; fourth principle consisting of the value of discussion/deliberation, creativity and innovation; and the fifth precept in the form of social sensitivity values. The characteristics of the five precepts integrated into both material and symbolic in the school science material module. The application of Pancasila values into the School Science Module Study Materials provides an understanding of science materials to students. It can also 


\section{The Developing of Modul on Science School Material with Pancasila Character}

form and bring out the character of students under the values of Pancasila.

The module validation by the validator is an assessment process to assess whether the product design module for the School Science Material Study has a valid Pancasila characteristic or not. Validation was carried out by a lecturer team consisting of lecturers in the field of science education experts and lecturers in the field of Pancasila and Citizenship Education expertise. Validation uses the expert judgment method. The results of the validation and suggestions for improvement from the validator are the addition of the Pancasila symbol/icon, the addition of an introductory module that shows the character of the Pancasila, the inclusion of a table of contents, and several improvements to the writing of words due to typographical errors. This suggestion is an evaluation and development of the module.

The results of the validator team's assessment of the School Science Material module with Pancasila characteristics as the subject of electricity and magnetism can see in Table 2.

Table 2. Results of module validation

\begin{tabular}{|c|c|c|c|}
\hline \multirow{2}{*}{ No } & \multirow[b]{2}{*}{ Aspect } & \multicolumn{2}{|c|}{ Score } \\
\hline & & I & II \\
\hline 1 & Instructional Objectives & 4 & 4 \\
\hline 2 & $\begin{array}{l}\text { Pancasila characteristics in } \\
\text { the module }\end{array}$ & 4 & 3 \\
\hline 3 & Fitness & 4 & 4 \\
\hline 4 & Rationality & 3 & 4 \\
\hline 5 & Language & 3 & 3 \\
\hline 6 & Module Content & 3 & 4 \\
\hline 7 & Flexibility & 3 & 3 \\
\hline 8 & Physical form & 3 & 3 \\
\hline Tot & Score & 27 & 28 \\
\hline Ave & & 27,5 & \\
\hline
\end{tabular}

Table 2 shows the average total score of the validator team showing 27.5. It indicates that the module of School Science Study Material characterized by Pancasila developed into the category of high validity.

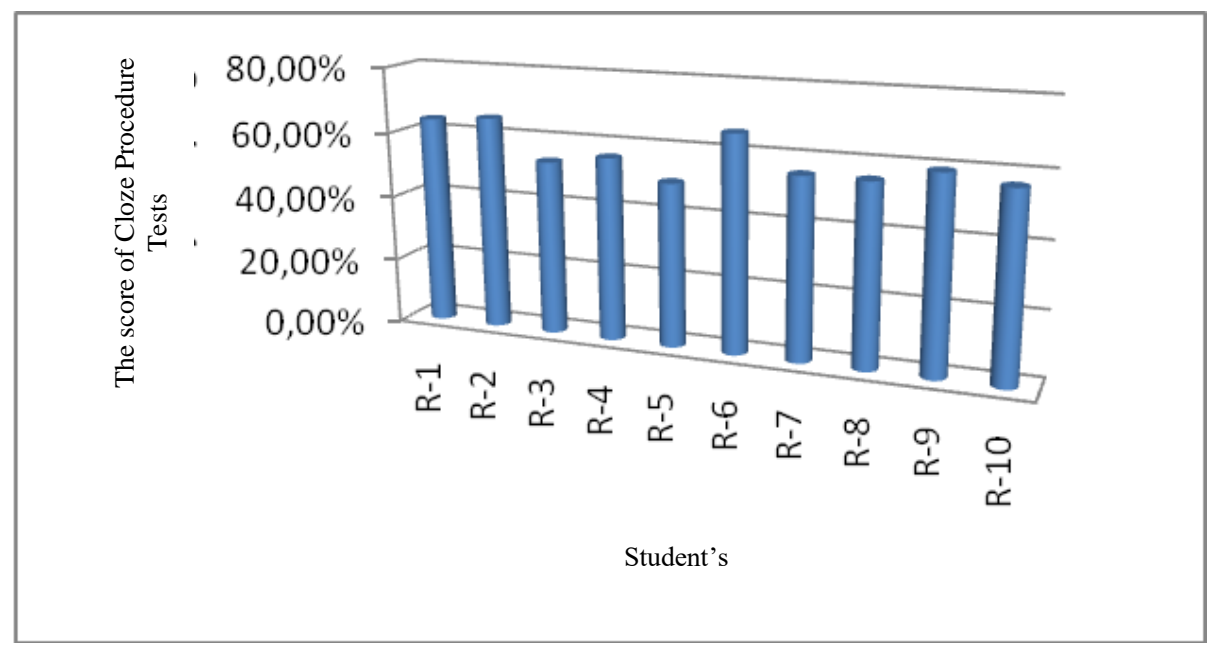

Figure 2. Chart of module readability test scores 
The level of readability of the module is testing with the cloze procedure test by passing the 10th word from the module. This test ride is a limited scale test, conducted on 10 students of the sixth semester of Science Education. The results of the cloze procedure test can see in Table 3 and Figure 2.

Table 3. Recapitulation of the module readability level results

\begin{tabular}{llc}
\hline No & \multicolumn{1}{c}{ Description } & $\begin{array}{c}\text { The score of Level } \\
\text { Readability }\end{array}$ \\
\hline 1 & Minimal score & $50 \%$ \\
2 & Maximal score & $66 \%$ \\
3 & Average & $58.1 \%$ \\
\hline
\end{tabular}

Table 3 shows the acquisition of the average score of the module readability level of $58.1 \%$. It shows that the module of School Science Study Material characterized by Pancasila developed in the category of teaching materials is easy to understand.

\section{Conclusion}

Based on the results of the study it can be concluded that: the module studying the science of school material characterized by Pancasila on the subject of electricity and magnetism that has been developed has the characteristics of Pancasila from the first precepts to the fifth precepts with an average validation score of 27.5 and categorized as high validity. The level of readability of the module Science School Study Material characterized by Pancasila, the subject of electricity and magnetism gained a score of readability level of $58.1 \%$ so that it was easily understood as a readability category. This module can be recommended to develop the character of Pancasila in students of science education study programs.

\section{References}

Dharmawan, N. S. (2014). Implementasi pendidikan karakter bangsa Pada mahasiswa di perguruan tinggi. Makalah dipresentasikan pada Pembinaan Pendidikan Karakter bagi Mahasiswa PTS di Lingkungan Kopertis Wilayah VIII, Universitas Udayana Denpasar.

Judiani, S. (2010). Implementasi Pendidikan Karakter di Sekolah Dasar melalui Penguatan Pelaksanaan Kurikulum. Jurnal Pendidikan dan Kebudayaan, 16(9), 280-289.

Khusniati, M. (2012). Pendidikan Karakter Melalui Pembelajaran IPA. Jurnal Pendidikan IPA Indonesia, 1(2).

Kompas. (2017). Mahasiswa Sains Berpotensi Jadi Radikal. https://kompas.id/baca/polhuk/pol itik/2017/03/09/mahasiswa-sainsberpot ensi-jadi-radikal/ (diakses 1 Mei 2017)

Kristiawan, M. (2016). Telaah Revolusi Mental dan Pendidikan Karakter dalam Pembentukkan Sumber Daya Manusia Indonesia Yang Pandai dan Berakhlak Mulia. Ta'dib, 18(1), 13-25.

Manullang, B. (2013). Grand Desain Pendidikan Karakter Generasi Emas 2045. Jurnal Pendidikan Karakter, (1).

Pendidikan IPA. (2015). Kurikulum Program Studi Pendidikan IPA Berbasis KKNI. Tegal: FKIP UPS Tegal

Rachmah, H. (2013). Nilai-Nilai dalam Pendidikan Karakter Bangsa yang 


\section{The Developing of Modul on Science School Material with Pancasila Character}

Berdasarkan Pancasila dan UUD 1945. E-Journal WIDYA NonEksakta, 1(1).

Republika. (2014). Nilai Pancasila Memudar di Kalangan Muda. http://www.republika.co.id/berita/ koran/didaktika/14/10/06/nd0jkb2 4-nilai -pancasila-memudar-dikalangan-muda (diakses 1 Mei 2017)

Sadiman, A., Rahardjo, R., Haryono, A., dan Rahardjito. (1996). Media Pendidikan. Jakarta: Pustekkom Dikbud dan Raja Grafindo Persada.

Schacter, J. (2006). Teacher performancebased accountability: why, what and

how.http://citeseerx.ist.psu.edu/vi ewdoc/download?doi=10.1.1.419. $6379 \&$ rep $=$ rep $1 \&$ type $=$ pdf (diunduh tanggal 8 Maret 2016).

Sudijono, A. (2008). Pengantar Statistika Pendidikan. Jakarta: Raja Grafindo.

Susanti, R. (2013). Penerapan pendidikan karakter di kalangan mahasiswa. Al-Ta lim Journal, 20(3), 480487.

Widodo, A. T. (1993). Tingkat Keterbacaan suatu Teks: Suatu Evaluasi terhadap Buku Teks Ilmu Kimia kelas satu Sekolah menengah Atas. Disertasi. Program pascasarjana IKIP Jakarta.

Wilujeng, I. (2012). Redesain Kurikulum S1 Pendidikan IPA Menuju Standards for Secondary Science Teacher Preparation". Prosiding. Seminar Nasional Penelitian, Pendidikan dan Penerapan MIPA di Universitas Negeri Yogyakarta. Yogyakarta, 2 Juni. 